\title{
Statistical Modelling of a Comparative Phytotoxicity Study of Treated Yellow 10Gw Dye Solution With Copper and Aluminum in Electrocoagulation Process
}

\author{
Kalivel Parameswari*, M. Vijila**† and P. Jegathambal ${ }^{* * *}$ \\ *Department of Chemistry, Karunya Institute of Technology and Sciences, Coimbatore-641114, Tamil Nadu, India \\ ***Department of Mathematics, Karunya Institute of Technology and Sciences, Coimbatore-641114, Tamil Nadu, India \\ ****Department of Water Institute, Karunya Institute of Technology and Sciences, Coimbatore-641114, Tamil Nadu, India \\ $\dagger$ Corresponding author: M. Vijila; vijilamoses@karunya.edu
}

\section{Nat. Env. \& Poll. Tech. \\ Website: www.neptjournal.com \\ Received: 15-06-2021 \\ Revised: 25-07-2021 \\ Accepted: 29-07-2021 \\ Key Words: \\ Electrocoagulation \\ Yellow $10 \mathrm{GW}$ dye \\ Analysis of variance \\ Linear trend}

\begin{abstract}
This work was carried to compare the efficiency of $\mathrm{Cu}$ and $\mathrm{Al}$ electrodes in the elimination of Yellow 10 gw dye solution with the optimization of operative factors such as $\mathrm{pH}, \mathrm{NaCl}$, contact time, and current density in the electrocoagulation method. Analysis of variance (ANOVA) was used to assess the impact of these variables, with significance set at $P<0.05$. The data was statistically examined with Origin2021 and SPSS software, and significant differences between mean values were determined using analysis of variance (ANOVA). For each experiment, duplicates were kept, and the efficiency of Yellow $10 \mathrm{gw}$ dye solution for those parameters was derived using analysis at a $5 \%$ level of significance. The utility of treated dye solutions using both the electrodes was tested on V.radiata in terms of germination percentage, root, and shoot length with distilled water as control. For all of the qualities examined, significant disparities were found among entries. The dye solution used with Al resulted in much higher germination $(100 \%)$, root length $(9.72 \mathrm{~cm})$, and shoot length $(24.5 \mathrm{~cm})$.
\end{abstract}

\section{INTRODUCTION}

Textile industry processes use a lot of water, particularly for wet processes like dying, and as a result, the wastewater generated contains synthetic dyestuffs. It has also been documented that nearly $10 \%$ of the dye is lost during the dyeing process due to a lack of fabric adherence (Garg \& Kaushik 2018). These synthetic dyes in water pollute and affect all water sources, including groundwater and surface water. They can have a negative impact on marine life, agricultural practices, and human health. Furthermore, the majority of the synthetic dyes used in these units have not been tested for their environmental and health effects. Chemical oxygen demand (COD), color, and salt levels in effluent from various units in a textile hub are all high, and the volume of water produced and discharged as waste by these sectors is rapidly expanding, and it contains a variety of contaminants (Rasalingam et al. 2014).

To treat the wastewater produced by the textile industries, methods like chemical, physical, biological, electrochemical are employed. Among which chemical treatments include coagulation, ozonation, advanced photochemical oxidation, (Glaze \& Chapin 1987, Marcucci et al. 2002, Molkenthin et al. 2013), filtration techniques such as reverse osmosis, nanofiltration (Merayo et al. 2013), ultrafiltration, and microfiltration using suitable membranes (Chakraborty et al. 2003, Wang et al. 2016). Each of these approaches has its own advantages, but they are all costly and time-consuming. Physical treatment, on the other hand, necessitates the use of extra chemicals and produces a significant volume of sludge.

Disperse dyes are one of the many forms of synthetic dyes available, and are non-ionic, sparingly soluble in water, and applied to hydrophobic fibers from an aqueous phase (Clark 2011). They are mostly used on polyester, but they have also been used on nylon, cellulose acetate, and acrylic fibers, however, some of the dyes' wet-fastness capabilities on these substrates are not great (Saquib \& Muneer 2003, Hassan et al. 2009). Diverse chromophores for instance azo, anthraquinone, and triphenylmethane, contribute to the structural diversity of synthetic disperse dyes. Azo dyes are the most common disperse type, accounting for more than half of all disperse dyes (Qiu et al. 2020). Due to their resistive character and non-biodegradable activity, these dyes are classified as persistent (Jamil et al. 2020, Shamey 2009). Anthraquinone dyes are the second most often used dyes after azo dyes because of their inexpensive cost, quick accessibility, and high dyeing effectiveness. Anthraquinone dyes are more harmful to microorganisms and human cells because they have a more complicated and stable structure than azo dyes (Novotnyet al. 2006). In contrast to azo dyes, 
the carbonyl group in the anthraquinone structure acts as an electron acceptor, requiring an electron donor to react and serve the structure; however, research reveals that anthraquinone dyes are difficult to degrade when compared to azo dyes (Mishra \& Maiti 2018). Thecombinedeffects of resonance in the anthracene structure make it more difficult to decolorize AQ colors than azo dyes (Lizama et al. 2001, Sekuljica et al. 2016), raising questions about the possibility of a successful decolorization operation (Khataee et al. 2016).

Photocatalytic oxidation (Samanta et al. 2018), Fenton oxidation (Lovato et al. 2017), ultrasonic catalytic oxidation (Santos et al. 2005) are some of the treatment methods for anthraquinone dye degradation. AOP is notable for its extremely fewer reaction times, typically a few minutes, high efficacy, and dye sedimentation on decolorization of AQ dyes, but it is also notable for its high cost, which makes scaling up difficult (Castro et al. 2014, Khataee \& Kasiri 2010).

Recent research has looked at biological strategies for AQ dye degradation in aerobic and anaerobic cultures (Cesaro \& Belgiorno 2013, Padmanaban et al. 2013). The challenge is to develop reliable, cost-effective, and environmentally sustainable bioremediation methods that overcome the limitations of traditional methods (Husain \& Ulber 2011, Li et al. 2019). There are also no data on the toxic, mutagenic, or carcinogenic intermediate products produced during the degradation of certain AQ colors, making it difficult to choose the correct type of treatment procedure.

Amongst the electrochemical methods, electrocoagulation does not involve any additional chemicals and is a relatively simple procedure that creates a small amount of sludge (Zhou et al. 2019) and it has become the focus of wastewater treatment research in recent years since it is easy to operate and produces less sludge. In this sense, electrocoagulation appears to be a viable alternative to physical and chemical methods since the procedure is simple to implement. EC appears to be a promising option for removing dissolved solids and colloidal particles from textile dyeing wastewater in the tertiary treatment stage. The efficacy in the dye abatement depends on the anodization, hydroxides production, size, and the colloidal properties of the particles. Reactive Blue 19 (Khoshhesab \& Ahmadi 2016) and basic Yellow 28 dye effluent were successfully eliminated using the EC technique (Gaber et al. 2013, Sangeetha et al. 2009), Red disperse, Blue reactive, and mixed dyes (Phalakornkule et al. 2010, Polgumhang et al. 201). Abatement of Yellow $10 \mathrm{gw}$ dye (a type of anthraquinone disperse dye) aqueous solution was studied in this work focusing on optimlze the operative parameters such as $\mathrm{pH}$, electrolyte, current density, and contact time for maximum abatement of the dye using two different electrodes, one with $\mathrm{Al}$ electrodes and the other with $\mathrm{Cu}$ electrodes and the findings were compared to the efficacy of the electrodes used.

An analytical technique like X-ray Photoelectron Spectroscopy (XPS) analysis was employed to investigate the efficiency of the EC process in the sludge separated. To examine the possibility of reusing the treated dye solution, phytotoxicity tests with V.radiata seeds were performed, and the results were compared to the control (distilled water) in terms of percent-age of germination, length of root, and shoot. We previously analyzed the performance of $\mathrm{Zn} / \mathrm{TiO}_{2}$ electrodes prepared by spray pyrolysis in treating Coralene Red $3 \mathrm{G}$ dye for color removal in electrocoagulation technique with optimization of operating parameters. The efficiency of color removal for parameters such as $\mathrm{pH}$, dye concentration, electrolyte, applied current, and time was estimated using design experts software and an ANOVA design model (Nayak \& Pal 2020, Praveen et al. 2011).

In another study, we had discussed and compared the efficiency of $\mathrm{Al}-\mathrm{Al}$ and $\mathrm{Cu}-\mathrm{Cu}$ electrodes in the elimination of Blue SI dye aqueous solution in the electrocoagulation process with the optimization of operational parameters such as $\mathrm{pH}$, the concentration of electrolyte, current density, and electrolysis time using design experts' software and the experimental data were analyzed by variance analysis (ANOVA) (Kalivel et al. 2019).

\section{MATERIALS AND METHODS}

Two sets of experiments were conducted with $\mathrm{Cu}$ and $\mathrm{Al}$ electrodes for optimization of operative factors such as contact time, $\mathrm{pH}$, current density, and electrolyte concentration for the abatement of Yellow $10 \mathrm{gw}$ dye solution.

For each process, $250 \mathrm{~mL}$ of the Yellow $10 \mathrm{gw}$ dye (150 $\mathrm{mg}$,) solution as test solution was taken in a $500 \mathrm{~mL}$ beaker with DC connection and stirrer. In the first set, we used $\mathrm{Al}$ as anode and cathode, in the next set of experiments $\mathrm{Cu}$ was used as anode and cathode, and the results were compared for each operational parameter used. The experiments were conducted at $25^{\circ} \mathrm{C}$. The consequence of initial $\mathrm{pH}(5,6,7$, $8,9)$, contact time $(5,10,15,20,25$ mins $)$, current density $\left(20,40,60,80\right.$, and $\left.100 \mathrm{Am}^{-2}\right)$ and electrolyte concentration (NaCl: 1 to $5 \mathrm{gm} . \mathrm{L}^{-1}$ ) were studied on the dye abatement. The dye absorbance was determined before and after the process with the Jasco V-670 spectrophotometer, and the dye concentration was assessed with the absorbance at $542 \mathrm{~nm}$.

Dye abatement efficiency (DAE \%) was calculated using the following

$$
\mathrm{DAE} \%=100 *\left(\mathrm{~A}_{\mathrm{a}}-\mathrm{A}_{\mathrm{b}}\right) / \mathrm{A}_{\mathrm{a}}
$$

Where $A_{a}$ and $A_{b}$ were the absorbance of dye solution before electrocoagulation and at time $t$, respectively. 


\section{Phytotoxicity Investigation}

Dye components can influence the entire photosynthesis process and eventually inhibit plant growth, even at very low concentrations in water, and dye degradation releases a range of intermediate products that must be non-toxic to the environment. To determine the likelihood of the treated water being reused, a phytotoxicity study was conducted on the growth of V.radiata seeds using a 150mg.L $\mathrm{L}^{-1}$ Yellow $10 \mathrm{gw}$ dye solution, a treated dye solution with $\mathrm{Al}$ and $\mathrm{Cu}$, and tap water as a control. Twenty sterilized seeds were placed in a $250 \mathrm{~mL}$ beaker with $150 \mathrm{~g}$ autoclaved soil and exposed to sunlight after being soaked in 0.1 percent $(\mathrm{w} / \mathrm{v})$ mercuric chloride and then splashed three times with distilled water to remove any traces of mercury.

With an equal volume of treated, untreated Yellow 10gw aqueous solution and tap water, the seed germination and plant growth were studied. Germination percentage, root, and shoot length were calculated after 10 days, and the results were compared to the control

$\%$ of Germination $=\frac{\text { number of seeds germinated }}{\text { Total number of seeds sown }} * 100$

\section{RESULTS AND DISCUSSION}

The effects of various parameters on the percentage of color removal of the Yellow $10 \mathrm{gw}$ dye aqueous solution were determined using analysis of variance (ANOVA). The p-value associated with the F statistics is used to assess if they are high enough to establish statistical significance (Kalivel et al. 2020). The regression model equation fitted by the curve is a second-order polynomial equation for the percentage color removal of Yellow $10 \mathrm{gw}$ dye aqueous solution as a function of $\mathrm{pH}(\mathrm{X} 1), \mathrm{NaCl}$ (X2), current density (X3), and contact time (X4) (Kunasekarn et al. 2017).
A phytotoxic investigation of treated Yellow $10 \mathrm{gw}$ dye solution with $\mathrm{Al}$ and $\mathrm{Cu}$ was carried out at room temperature for 10 days in a seed germinator, with statistical modeling used to determine the significance level of dye removal efficiency. Yellow $10 \mathrm{gw}$ dye solution removal efficiency was taken as the second-order polynomial equation.

$$
\mathrm{Yi}=\mathrm{b}_{0}+\sum \mathrm{b}_{\mathrm{i}} \mathrm{x}_{\mathrm{i}}+\sum \mathrm{b}_{\mathrm{ii}} \mathrm{x}_{\mathrm{ij}}{ }^{2}+\sum \sum \mathrm{b}_{\mathrm{ij}} \mathrm{x}_{\mathrm{i}} \mathrm{x}_{\mathrm{j}}
$$

Where $Y_{i}$ is the amount of efficiency of removing the dye

$\mathrm{b}_{0}=$ Constant coefficient

$b_{i}=$ Regression coefficients for linear effects

$\mathrm{b}_{\mathrm{ii}}=$ Quadratic coefficients

$\mathrm{b}_{\mathrm{ij}}=$ Interaction coefficients and $\mathrm{x}_{\mathrm{i}}, \mathrm{x}_{\mathrm{j}}$ are the parameters.

$\begin{array}{lcll}\text { Std. Dev. } & 0.0004 & \mathrm{R}^{2} & 0.312 \\ \text { Mean } & 0.0101 & \text { Adjusted } \mathrm{R}^{2} & 0.429 \\ \text { C.V. \% } & 4.18 & \text { Predicted } \mathrm{R}^{2} & -0.3459 \\ & & \text { Adeq Precision } & 4.5474\end{array}$

When comparing $\mathrm{pH}$ to time, the $\mathrm{r}^{2}$ value was 0.312 , which was significant at $\mathrm{P}<0.05$. In the current study, this method was used to measure the effectiveness of adsorption of the Yellow $10 \mathrm{Gw}$ dye solution under a variety of conditions, including $\mathrm{pH}, \mathrm{NaCl}$, current density, and contact time.

From Table 1, we found no statistically significant ( $\mathrm{p}$ $>0.05$ ) differences in $\mathrm{pH}$ for $\mathrm{Cu}$ electrodes. Therefore, we could not conclude that the model explains variation in the operational behaviors such as $\mathrm{pH}, \mathrm{NaCl}$, contact time, and current density.

Fig. 1 reveals that some of the variances in the response are attributable to time, and the graphs are not randomly spread, implying that for $\mathrm{Cu}$ electrodes, a non-linear regression method is recommended.

Table 2 shows that there was a statistically significant ( $\mathrm{p}$ 0.05 ) difference in $\mathrm{pH}$ for $\mathrm{Al}$ electrodes depending on the

Table 1: $\mathrm{pH}$ with Time in $\mathrm{Cu}$ electrodes.

\begin{tabular}{|llllll|}
\hline Source & Sum of Squares & Df & Mean Square & F-value & p-value \\
\hline B-Time & $1.016 \mathrm{E}-07$ & 1 & $1.016 \mathrm{E}-07$ & 0.5654 & 0.4613 \\
$\mathrm{~A}^{2}$ & $1.428 \mathrm{E}-07$ & 1 & $1.428 \mathrm{E}-07$ & 0.7951 & 0.3837 \\
$\mathrm{AB}$ & $4.185 \mathrm{E}-07$ & 1 & $4.185 \mathrm{E}-07$ & 2.33 & 0.1434 \\
$\mathrm{~A}-\mathrm{pH}$ & $4.870 \mathrm{E}-07$ & 1 & $4.870 \mathrm{E}-07$ & 2.71 & 0.1161 \\
$\mathrm{~B}^{2}$ & $7.492 \mathrm{E}-07$ & 1 & $7.492 \mathrm{E}-07$ & 4.17 & 0.0553 \\
Model & $1.615 \mathrm{E}-06$ & 5 & $3.230 \mathrm{E}-07$ & 1.80 & 0.1615 \\
Residual & $3.413 \mathrm{E}-06$ & 19 & $1.796 \mathrm{E}-07$ & & not significant \\
Total & $5.028 \mathrm{E}-06$ & 24 & & & \\
\hline
\end{tabular}


time period. Therefore, there is enough evidence to say that the model explains variation in the operational behaviors such as $\mathrm{pH}, \mathrm{NaCl}$, contact time, and current density.

Fig. 2 suggests that some of the variations in the response are due to contact time. As the pattern is quite random, this indicates that a linear regression model is appropriate for $\mathrm{Al}$ electrodes.

The F-value of 2.90 indicates that it is statistically significant at the $5 \%$ level.

\section{Phytotoxicity study on $V$. radiata}

When comparing Yellow 10gw dye solution with treated dye solution utilizing $\mathrm{Al}, \mathrm{Cu}$ in this study, the value of $\mathrm{r} 2$ was 0.378 (significant at $\mathrm{P}>0.05$ ). We discovered that plant's root and shoot length grown in Yellow 10gw dye solution treated with $\mathrm{Al}$ electrodes resulted in increased length of both.

According to Fig. 3 and 4, Al electrodes were the best when compared to other electrodes.
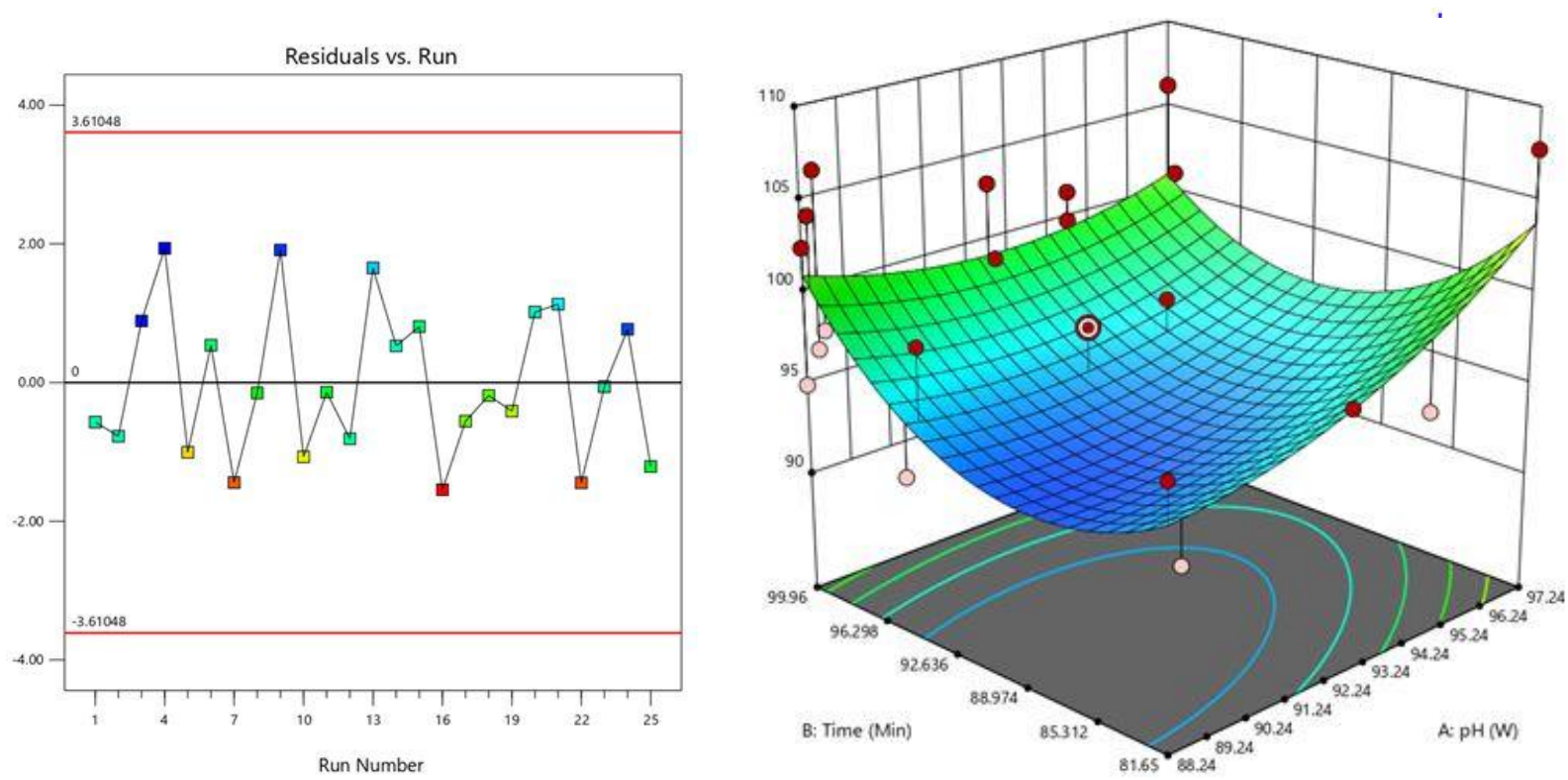

Fig. 1: Residual and surface diagram for $\mathrm{pH}$ Vs contact time.
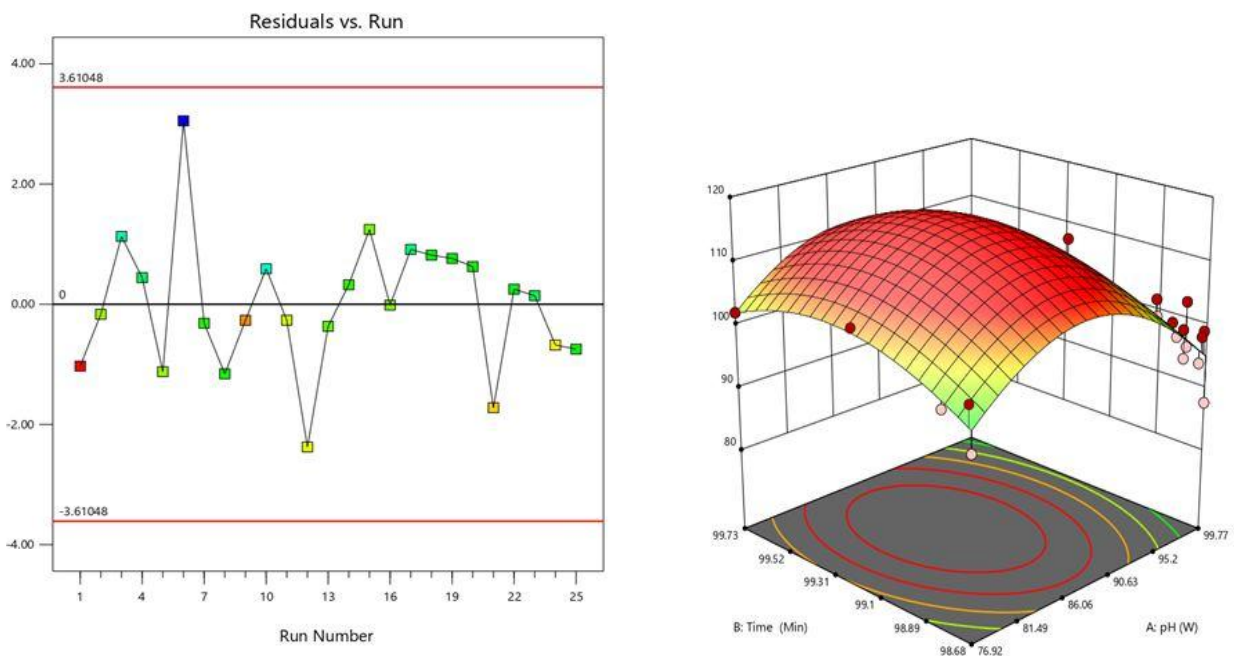

Fig. 2: Residual and surface diagram for $\mathrm{pH}$ Vs contact time 
Table 2: $\mathrm{pH}$ with contact time in $\mathrm{Al}$ electrodes.

\begin{tabular}{|lllllll|}
\hline Source & Sum of Squares & Df & Mean Square & F-value & p-value \\
\hline Model & $2.161 \mathrm{E}-06$ & 5 & $4.322 \mathrm{E}-07$ & 2.90 & 3.04 & 0.0411 \\
A-pH & $4.532 \mathrm{E}-07$ & 1 & $4.532 \mathrm{E}-07$ & 1.33 & 0.0971 \\
B-Time & $1.974 \mathrm{E}-07$ & 1 & $1.974 \mathrm{E}-07$ & 0.1269 & 0.7256 \\
$\mathrm{AB}$ & $1.889 \mathrm{E}-08$ & 1 & $1.889 \mathrm{E}-08$ & 4.34 & 0.0511 \\
$\mathrm{~A}^{2}$ & $6.453 \mathrm{E}-07$ & 1 & $6.453 \mathrm{E}-07$ & 7.15 & 0.0150 \\
$\mathrm{~B}^{2}$ & $1.064 \mathrm{E}-06$ & 1 & $1.064 \mathrm{E}-06$ & & \\
Residual & $2.828 \mathrm{E}-06$ & 19 & $1.488 \mathrm{E}-07$ & & \\
Total & $4.989 \mathrm{E}-06$ & 24 & & & \\
\hline
\end{tabular}

\section{XPS Analysis of Sludge}

$\mathrm{Al}$ and $\mathrm{Cu}$ XPS survey spectra as well as high-resolution core line spectra [( $\mathrm{Al}, \mathrm{Al} 2 \mathrm{p})$ and $\left.\left(\mathrm{Cu}, \mathrm{Cu} 2 \mathrm{p}^{3}\right)\right](\mathrm{a}-\mathrm{d})$ are given in Fig. 5. It has been claimed that the capacity of Al to generate dimeric, trimeric, and polynuclear hydrolysis products can be formed during the anodization process (Saha et al. 2015,
Jeurgens et al. 2002, Liu et al. 2016).

However, the development of different forms of $\mathrm{M}(\mathrm{OH})$ $\mathrm{n}$ is dependent on various factors, including the composition of the anode metal during anodization, hydroxides from the cathode, and so on. This study contributes to a better understanding of the electrochemistry of metal hydroxide
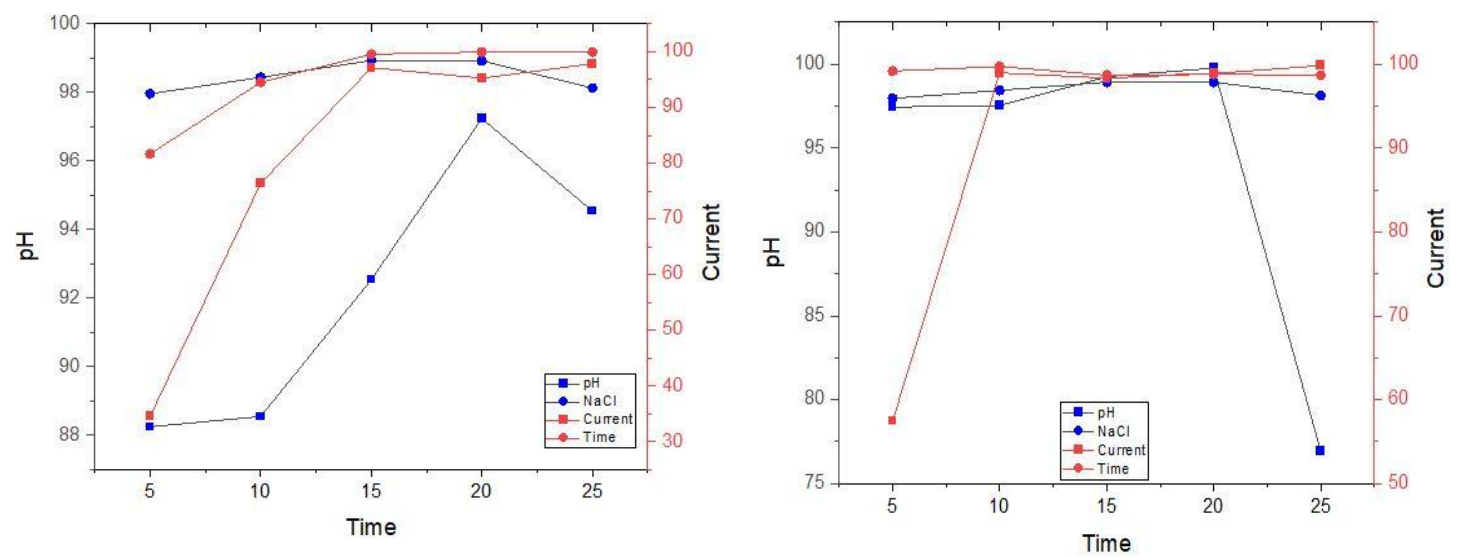

Fig. 3: Linear trend for phytotoxicity of dye solution and the treated dye solution using $\mathrm{Al}, \mathrm{Cu}$
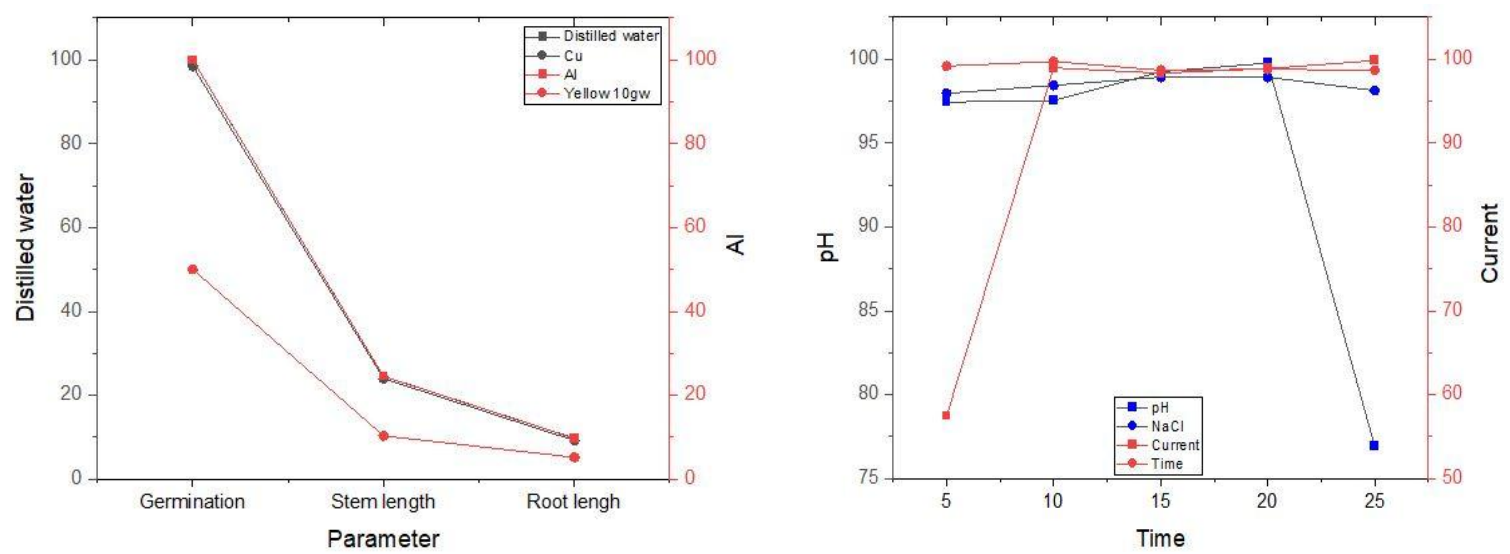

Fig. 4: Linear trend for phytotoxicity of dye solution and the treated dye solution using $\mathrm{Al}$ and $\mathrm{Cu}$. 
Table 3: Overall statistics and analysis of variance.

Descriptive statistics for phytotoxicity of Yellow $10 \mathrm{gw}$ dye solution treated dye solution using $\mathrm{Al}$

\begin{tabular}{|lllll|}
\hline & Sample Size & Mean & Standard Deviation & SE of Mean \\
\hline Germination & 10 & 86.028 & 30.90759 & 9.77384 \\
Stem & 10 & 39.609 & 31.82887 & 10.06517 \\
\hline
\end{tabular}

ANOVA for phytotoxicity of Yellow $10 \mathrm{gw}$ dye solution Vs treated dye solution using Al

\begin{tabular}{|llllll|}
\hline Source & df & Sum of Squares & Mean Square & F Value & Prob $>$ F \\
\hline Model1 & 10 & 773.6178 & 10773.6178 & 10.94682 & 0.00391 \\
Error & 18 & 17715.20085 & 984.17783 & & \\
Total & 19 & 28488.81866 & & & \\
\hline
\end{tabular}

Fit statistics

\begin{tabular}{|clll|}
\hline R-Square & Coeff Var & Root MSE & Data Mean \\
\hline 0.37817 & 0.4994 & 31.37161 & 62.8185 \\
\hline
\end{tabular}
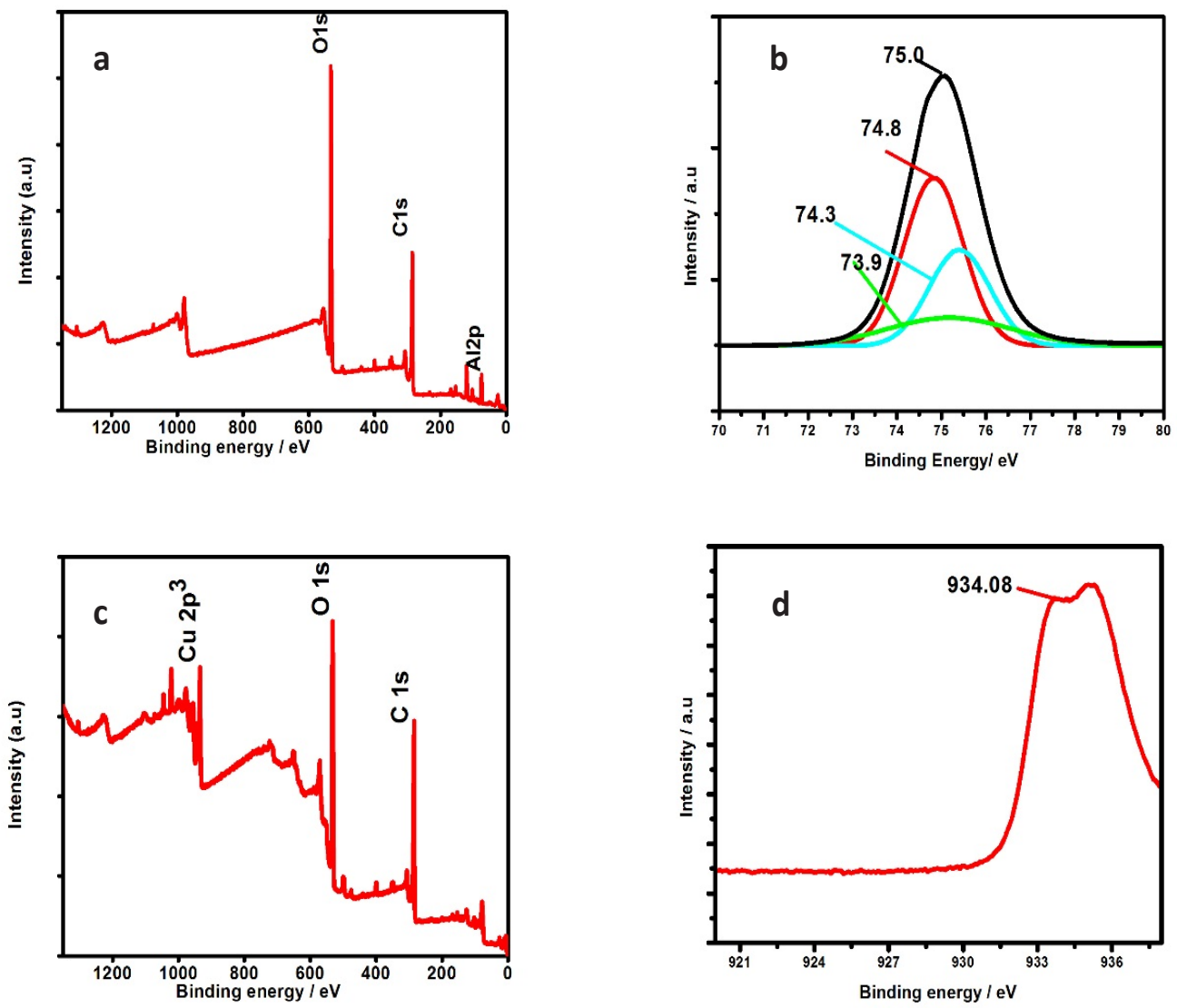

Fig. 5: $\mathrm{Al}$ and $\mathrm{Cu}$ XPS survey spectra and high-resolution core line spectra [( $\mathrm{Al}, \mathrm{Al} 2 \mathrm{p})$ and $(\mathrm{Cu}, \mathrm{Cu} 2 \mathrm{p} 3)]$. 
formations, as well as a better understanding of the different types of metal hydroxides that are produced, which aids in the coagulation of dye molecules and the evaluation of the electrodes' efficacy in the removal of dye pollutants. From the high-resolution core spectra of Al2p, the binding energy value of $\mathrm{Al}$ as gibbsite $74.4 \mathrm{eV}\left[\gamma-\mathrm{Al}(\mathrm{OH})_{3}\right]$, bayerite $\left[\mathrm{Al}(\mathrm{OH})_{3}\right] 75.0 \mathrm{eV}\left[\mathrm{Al}(\mathrm{OH})_{3}\right]$, boehmite $[\mathrm{AlO}(\mathrm{OH})] 73.9$ $\mathrm{eV}$ and pseudoboehmite $[\mathrm{AlO}(\mathrm{OH})] 74.3 \mathrm{eV}$ were found and it was noteworthy to conclude that there are four types of hydroxides of $\mathrm{Al}$ formed, such as $\left[\mathrm{Al}(\mathrm{OH})_{3}\right]$ gibbsite, $\left[\mathrm{Al}(\mathrm{OH})_{3}\right]$ bayerite, $[\mathrm{AlO}(\mathrm{OH})]$ boehmite and $[\mathrm{AlO}(\mathrm{OH})]$ pseudoboehmite.

XPS analysis of copper electrodes revealed a binding energy value of $934.06 \mathrm{eV}$ for copper in its +2 oxidation state, showing that the metal hydroxide as flocs formed in the EC operation with copper was $\mathrm{Cu}(\mathrm{OH}) 2$, which was supported by published work (Kloprogge et al. 2006). The efficacy of $\mathrm{Al}$ metal over $\mathrm{Cu}$ was substantiated by XPS studies of the respective sludge in the process.

\section{CONCLUSION}

The percentage of Yellow 10gw dye removed from aqueous solution using $\mathrm{Cu}$ and $\mathrm{Al}$ electrodes in the EC method exhibits a linear relationship with $\mathrm{pH}$, electrolyte concentration, contact time, and current density, and with a substantial interaction between the amount of adsorbent and dye concentration. The use of $\mathrm{Al}$ exhibited better results in the germination, root, and shoot length of V.radiata than the dye solution used with $\mathrm{Cu}$ electrodes in comparison to the control in the phytotoxicity research of V.radiata with treated dye solutions. The improved performance of Al was demonstrated by XPS analysis of the corresponding sludge, which revealed four different types of hydroxides as adsorbents in the $\mathrm{Al}$ process versus just one hydroxide from the process used with copper electrodes.

\section{REFERENCES}

Castro, E., Avellaneda, A. and Marco, P. 2014. Combination of advanced oxidation processes and biological treatment for the removal of benzidine-derived dyes. Environ. Prog. Sustain. Energy, 33(3): 873-885.

Cesaro, A.N.V. and Belgiorno. V. 2013. Wastewater treatment by a combination of advanced oxidation processes and conventional biological systems. J. Biorem. Biodegrad., 15: 208.

Chakraborty, S.M.K., Purkait, S., Das Gupta, De, S. and Basu, J.K. 2003. Nanofiltration of textile plant effluent for color removal and reduction in COD. Sep. Purif. Technol., 31: 141-151.

Clark, M. 2011. Fundamental principles of dyeing, Handb. Text. Ind. Dye. Princ. Process.Types Dyes, 1:2-11

Gaber, M., Ghalwa, N.A., Khedr, A.M. and Salem, M. F. 2013. Electrochemical degradation of reactive yellow 160 dyein real wastewater using $\mathrm{C} / \mathrm{PbO}-\overline{2}, \mathrm{~Pb}+\mathrm{Sn} / \mathrm{PbO}_{2}+\mathrm{SnO}_{2}^{-}$, and $\mathrm{Pb} / \mathrm{PbO}_{2}$ modified electrodes. Chemosphere, 5(1):1-7.

Garg, V.K. and Kaushik, P. 2018. Influence of textile mill wastewater irrigation on the growth of sorghum cultivars, Appl. Ecol. Environ. Res., 6: 1-12.

Glaze, W., and Chapin, D. 1987, The chemistry of water treatment processes involving ozone, hydrogen peroxide, and ultraviolet radiation. Ozone: Sci. Eng., 9: 335-342.

Hassan, S.S., Awwad, N.S. and Aboterika, A.H. 2009. Removal of synthetic reactive dyes from textile wastewater by Sorel's cement. J. Hazard. Mater. 162(2): 994-999.

Husain, Q., and Ulber, R. 2011. Immobilized peroxidase as a valuable tool in the remediation of aromatic pollutants and xenobiotic compounds: A review. Crit. Rev. Environ. Sci.Technol., 41(8): 770-804.

Jamil, A., Bokhari, T.H., Javed, T., Mustafa, R., Sajid, M., Noreen, S., Zuber, M., Nazir, A., Iqbal, M. and Jilani, M.I. 2020. Photocatalytic degradation of disperse dye Violet-26 using TiO 2 and $\mathrm{ZnO}$ nanomaterials and process variable optimization. J. Mater. Res. Technol., 9(1): 1119-1128.

Jeurgens, L.P.H., Sloof, W.G., Tichelaar, F.D. and Mittemeijer, E.J. 2002. Composition and chemical state of the ions of aluminium-oxide films formed by thermal oxidation of aluminium. Surf. Sci., 506: 313-332.

Kalivel, P., Palanichamy, J. and Vijila, M. 2019. Efficient removal of coralline red $3 \mathrm{G}$ dye in $\mathrm{EC}$ process with $\mathrm{Zn} / \mathrm{TiO} 2$ using a statistical algorithm. Int. J. Recent Technol. Eng., 61: 2277-3878.

Kalivel, P., Vijila, M. and Palanichamy, J. 2020. Optimization of color re- moval of blue si dye with al, $\mathrm{Cu}$ electrodes in electrocoagulation process using statistical modeling, optimization of color removal of blue SI dye with $\mathrm{Al}$, Cu electrodes in electrocoagulation process using statistical modeling. EM Int., 39(3): 778-783.

Khataee, A., Gholami, P., Vahid, B. and Joo, S.W. 2016. Heterogeneous sono-Fenton process using pyrite nanorods prepared by-thermal plasma for degradation of an anthraquinone dye. Ultrason. Sonochem., 32: 357-370.

Khataee, A.R. and Kasiri, M.B. 2010. Photocatalytic degradation of organic dyes in the presence of nanostructured titanium dioxide: Influence of the chemical structure of dyes. J. Mol. Catal. A: Chem., 328(1-2): 8-26.

Khoshhesab, Z.M. and Ahmadi, M. 2016. Removal of reactive blue 19 from aqueous solutions using $\mathrm{NiO}$ nanoparticles: equilibrium and kinetic studies. Desalin. Water Treat., 57(42): 20037-20048.

Kloprogge, J.T., Loc, Duong, V., Barry, Wood, J. and Frost, R. L. 2006. XPS study of the major minerals in bauxite: Gibbsite, bayerite, and (pseudo) boehmite. J. Coll. Inter. Sci., 296(2): 572-576.

Kunasekarn, R., Kulandaivelu, G. and Arumugam, Y. 2017. Correlation analysis for shoot/root parameters under polyethylene glycol (PEG) induced water stress in sorghum (Sorghum bicolor (L.) Moench) genotypes. Int. J. Chemical Stud., 5(6): 389-399.

Li, H.H., Wang, Y.T., Wang, Y., Wang, H.X., Sun, K.K. and Lu, Z.M. 2019. Bacterial degradation of anthraquinone dyes. J. Zhejiang Univ. Sci., 20(6): 528-540.

Liu, Q., Qin, H., Boscoboinik, J.A. and Zhou, G. 2016. Comparative study of the oxidation of NiAl (100) by molecular oxygen and water vapor using ambient-pressure x-ray photoelectron pectroscopy. Langm, 32: 11414-11421.

Lizama, C., Freer, J., Baeza, J. and Mansilla, H.D. 2001. Optimized photodegradation of reactive blue 19 on $\mathrm{TiO}_{2}$ and $\mathrm{ZnO}$ suspensions. Catal. Today, 76(2-4): 235-246.

Lovato, M.E., Fiasconaro, M.L. and Martin, C.A. 2017. Degradation and toxicity depletion of RB19 anthraquinone dye in water by ozone-based technologies. Water Sci. Technol. 75(4) 813-822.

Marcucci, M., Ciardelli, G., Matteucci, A., Ranieri, L. and Russo M. 2002. Experimental campaigns on textile wastewater for reuse by means of different membrane processes. Elsevier Sci., 149: 137-143. 
Merayo, N., Hermosilla, D., Blanco, L., Cortijo, L. and Blanco, A. 2013. Assessing the application of advanced oxidation processes, and their combination with biological treatment to effluents from the pulp and paper industry. J. Hazard. Mater., 26: 420-427.

Mishra, S. and Maiti, A. 2018. The efficacy of bacterial species to decolorize reactive azo, anthraquinone, and triphenylmethane dyes from wastewater: A review. Environ. Sci. Pollut. Res., 25(9): 8286-8314.

Molkenthin, M., Olmez-Hanci, T., Jekel, M.R. and Alaton, I.A. 2013. Photo-Fenton-like treatment of BPA: Effect of UV light source and water matrix on toxicity and transformation products. Water Res., 47: 5052-5064.

Nayak, A.K. and Pal, A. 2020. Statistical modeling and performance evaluation of biosorption removal of Nile blue A by lignocellulosic agricultural waste under the application of high-strength dye concentrations. J. Environ. Chem. Eng., 8(2): 116-136.

Novotny, C., Dias, N., Kapanen, A., Malachova, K., Vandrovcova, M., Itavaara, M. and Lima, N. 2006. Comparative use of bacterial, algal, and protozoan tests to study the toxicity of azo- and anthraquinone dyes. Chemosphere, 63(9): 1436-1442.

Padmanaban, V.C., Prakash, S.S., Sherildas, P., Jacob, J.P. and Nelliparambil, K. 2013. Biodegradation of anthraquinone-based compounds: Review. Int. J. Adv. Res. Eng. Technol., 4: 15-39.

Polgumhang, C., Tongdaung, W., Karakat, B. and Nuyut, T. 2010. Electrocoagulation of blue reactive, red disperses and mixed dyes, and application in treating textile effluent, J. Environ. Manage., 91(4): 918-926.

Praveen, K.C., Radha, K.V. and Balasubramanian, N. 2011. Electrochemical treatment of plating effluent: Kinetics and statistical modeling. Arch. Environ. Sci., 5: 17-23

Qiu, J., Tang, B., Ju, B., Zhang, S. and Jin, X. 2020. Clean synthesis of disperses azo dyes based on peculiar stable 2,6- dibromo-4-nitrophenyl diazonium sulfate. Dyes Pigments, 17: 107920

Rasalingam, S., Peng, R. and Koodali, R. T. 2014. Removal of hazardous pollutants from wastewaters: Applications of $\mathrm{TiO}_{2}-\mathrm{SiO}_{2}$ mixed oxide materials. J. Nanomater., 11(3): 42.

Saha, G., Shihabudheen, Maliyekkal, M., Sabumon, P.C. and Pradeep, T. 2015. A low-cost approach to synthesize sand-like AlOOH nanoarchitecture (SANA) and its application in defluoridation of water. J. Environ. Chem. Eng., 3: 1303-1311.

Samanta, M., Mukherjee, M., Ghorai, U.K., Sarkar, S., Bose, C. and Chattopadhyay, K.K. 2018. Ultrasound-assisted catalytic degradation of textile dye under the presence of reduced graphene oxide enveloped copper-phthalocyanine nanotube. Appl. Surf. Sci., 449: 113-121.

Sangeetha, R., Lee, C.W., Chellammal, S., Palanichamy, C.S. and Basha, A. 2009. Evaluation of electrochemical oxidation techniques for degradation of dye effluents: A comparative approach. J. Hazard. Mater., 171(15): 748-754.

Santos, A.B.D., Bisschops, I.A.E., Cervantes, F.J. and van Lier, J.B., 2005. The transformation and toxicity of anthraquinone dyes during thermophilic (55 degrees C) and mesophilic (30 degrees C) anaerobic treatments. J. Biotechnol., 115(4): 345-353.

Saquib, M. and Muneer, M. 2003, TiO 2-mediated photocatalytic degradation of a triphenyl-methane dye (gentian violet), in aqueous suspensions. Dyes Pigments, 56(1): 37-49.

Sekuljica, N.Z., Prlainovic, N.Z., Jovanovic, J.R., Stefanovic, A. B., Djokic, V. R., Mijin, D.Z. and Jugovic, Z.D.K. 2016. Immobilization of horseradish peroxidase onto kaolin. Bioprocess Biosyst. Eng., 39(3): 461-472.

Shamey, R. 2009. 12 - Improving the coloration/dyeability of polyolefin fibers. In Ugbolue, S.C.O (Ed.), Polyolefin Fibres. Woodhead Publishing, Sawston, UK, pp. 363-397.

Wang, Z., Xue, M., Huang, K. and Liu, Z. 2016. Textile dyeing wastewater treatment. Adv. Treat. Text. Effluent, 2(3): $11-21$

Zhou, X., Zhou, Y., Liu, J., Song, S., Sun, J., Zhu, G., Gong, H., Wang, L., $\mathrm{Wu}, \mathrm{C}$. and Li, M. 2019. Study on the pollution characteristics and emission factors of PCDD/Fs from dispersing dye production in China. Chemosphere, 228: 328-334. 